\title{
The Act of Promise and Threat in Translated Verses of Law in The Qur'an
}

\author{
Nurul Chojimah \\ State College for Islamic Studies Tulungagung \\ Email: nurulchoy2@yahoo.com
}

\begin{abstract}
This study was aimed at finding the patterns of promise and threat in translated verses of law in the Qur'an and their syntactical realization. The data source for this research is the translated Qur'an published by the Ministry of Religious Affairs of the Republic of Indonesia. Data for this research are verses of law in marriage, inheritance, and trade containing the acts of promise and threat. The data were collected by reading and note-taking technique.The coding system by BlumKulka et al (1989) was adapted to analyze data for the study. It was found that the patterns of promise in translated verses of law can be classified into directive-commissive-conditional promise (DCCP), commissive-conditional promise (CCP), and neither-directive-nor-conditional promise (NDNCP). Directive-commissive-conditional threat (DCCT) is the only pattern of threat occurring in this study. Those speech acts are realized through conditional sentences and simple sentences. The conclusion is that the linguistic balance in the Qur'an can be found not only at the level of word and phrase, but also at the speech act level.
\end{abstract}

Keywords: promise, threat, speech act, verses of law, the Qur'an

\section{INTRODUCTION}

Two of the hallmarks of the Qur'an are that it is linguistically beautiful and substantially comprehensive. The beauty of the linguistic aspect can be seen from, among other things, its lexical choices. The word hayat (live) and its antonym:,mati (dead), are repated at the same frequency: 145 times. Likewise, the diction malaikat (angel) and its opponent, setan (satan), appear 88 times. The choice of the word panas (hot) occurs as frequently as its antonym, dingin (cold), that is four (4) times (Shihab, 1996: 5). Besides, it is substantially comprehensive. It contains rules of entire systems of life. It prescribes how humans should interact vertically and horizontally, and it shows humans' rights and obligations. In addition, it encourages actions humans should do, and it restricts deeds humans should not do. As such, reading the content of the Qur'an is the first requirement in order to comprehend the rules of the life systems.

The problem is that the Qur'an is sent down in Arabic as explicitly stated in Surah 12, verse 2 (QS [12]: 2). As a matter of fact, not all Muslims worldwide are knowledagble with Arabic. Relying on this fact, the Qur'an is translated into various languages, including Indonesian. Despite the deviation that might appear in the translation, the translated verses could be a very good medium for some Muslims to learn and comprehend the content of the holy book. Through the translated verses, Muslims can learn many aspects of the Qur'an, including the aspect of linguistics and the aspect of the rules of life prescribed by Islam, including laws.

Muamalah law is a set of rules of life which is comprehensively discussed in the Qur'an. Khallaf, in his book lists seven domains of muamalah law. The law that deals with marriage, divorce, inheritance, guardianship and other related matters 
is discussed within 70 verses, and the one related to human relation or civil law is presented in 70 verses. Rules concerning how to manage criminal issues are explained in 30 verses, and the ones related to justice, testimony, and oath are touched upon in 13 verses. Other rules discussed in the Qur'an are the ones related to constitution, international relationship, and economic and finance, each of which is respectively discussed within 10, 25, and 10 verses (32-36: 1947).

Laws, including the ones in the Qur'an, inherently bind humans. Humans, across ages, gender, and ethnicity are bound by the laws. It suggests that all people have to obey the laws. Relying on this property, laws are generally provided with sanctions for those breaking them. Fines and imprisonment are the common punishment for law breakers. Laws in the Qur'an do not make any difference, in the sense that the outlined laws are followed by sanctions. Those sanctions are generally preceded by warnings, and closed with threats and/or promises. Warnings and threats are addressed for those breaking the laws, but promises are made for those obeying the laws.

For example, law of inheritance, which is stated in the Surah An-nisa' verses 7 up to 14, is provided with a warning and a threat. The warning is stated in verse 9. It says: 'Dan hendaklah takut kepada Allah orang-orang yang seandainya meninggalkan di belakang mereka ana-anak yang lemah, yang mereka khawatir terhadap (kesejahteraan) mereka. Oleh sebab itu hendaklah mereka bertaqwa kepada Allah dan hendaklah mereka mengucapkan perkataan yang benar.' The first sentence of the verse saying dan hendaklah takut kepada Allah orang-orang yang seandainya meninggalkan di belakang mereka ana-anak yang lemah, yang mereka khawatir terhadap (kesejahteraan) mereka is a warning. The marker indicating the warning is the phrase dan hendaklah takut or and let those (executors and guardians) have the same fear... The phrase suggests that leaving weak offspring might bring about something bad in the future. A promise is made among those verses, in particular in verse 13. It says: '(Hukum-hukum tersebut) itu adalah ketentuan-ketentuan dari Allah. Barangsiapa taat kepada Allah dan RasulNya, niscaya Allah memasukkannya ke dalam surga yang di dalamnya mengalir sungai-sungai, sedang mereka kekal di dalamnya, dan itulah kemenangan yang besar.' The last sentence of the verse, the one written in bold, contains two clauses having a term-and-condition relationship. The first clause of it saying barangsiapa taat kepada Allah dan Rasulnya is the condition that must be fulfilled in order for the promise in the second clauseniscaya Allah memasukkannya ke dalam surga yang di dalamnya mengalir sungai-sungai, sedang mereka kekal di dalamnya, dan itulah kemenangan yang besar - can be made. The act of promising is recognizable from the use of niscaya or sure will. The sentence containing the word niscaya suggests that Allah will surely let those obeying the laws enter gardens in which rivers flow underneath; and they dwell forever.

These initial findings suggest that pragmatic features, in particular speech act, frequently occur within the verses of law. The acts of warning, threatening, and promising touched on earlier are the evidence of the pragmatic features. Such acts are called commissive acts, that is: the acts indicating a speaker's commitment to future actions (Searle, 1976: 11). With the reference of previous studies suggesting that verses in the Qur'an are linguistically patterned, I believe that acts in the verses of law are patterned as well.

Referring to this idea, I am in the opinion that a study on the patterns of commissive acts within the translated verses of law is worth conducting. Given that there is a considerable number of verses of law, this research focuses on the law of marriage, inheritance, and trading. This decision is under the consideration that inheritance, marriage, and trading contain rules to which almost all people are concerned with. As such, verses dealing with them are frequently read by people, and in consequence, it can influence people's minds.

This research is aimed at finding out: (1) the acts of promise and threat in translated verses of law in the Qur'an; (2) the patterns of their syntactical realization. Data for this research are translated verses of law in marriage, inheritance, and trade containing the acts of promise and threat. Any translated verses of law in those domains which do not contain promise and threat are excluded from the data. The data source of the research is the translated Qur'an published by the Ministry of the Religious Affairs of the 
Republic of Indonesia. The data were collected by reading and note-taking technique by which I read carefully the verses of law in those domains. As the acts of promise and threat appeared, they were noted. The data collection phase and data analysis were conducted simultaneously. Determining the acts of promise and threat and their syntactical realizations, I adapted the coding system in the Cross-Cultural Speech Act Realization Project (CCSARP) by Blum-Kulka et al (1989).

Commissive act is included in both Austin's (1975) and Searle's (1975) classification of illocutionary act. Two illocutionary acts including in commissive act are promise and threat. In general, promise can be understood as a statement stating that a speaker certainly would like to do something. Wierzbicka states that promise is a way by which the speaker binds himself to doing a certain action and relieves the addressee from his uncertainty (cited in Al-Jawadi \& Abdul-Majeed, 2007: 287).

Concerning the difference between promises and threats, Searle (1983: 58) specified that promise is a pledge to do something for you, not to you, while threat is a pledge to do something to you, not for you. In addition, Salguiro (2010: 219225 ) addresses the difference or the asymmetry between promises and threats in regard to explicitness, deontic, and illocution/perlocution. Regarding explicitness, in English, it is perfectly normal to make a promise explicit by using a performative verb promise, but it is not common to use a performative verb threaten when threatening others. As such, saying I promise to... is normal, but $I$ threaten... is not. Dealing with deontic, it can be underlined that it deals with the obligation of the speaker to keep his/her words. In promise, a promisor is obliged to keep his/her promise, without which the promise is broken, while threats appear to generate no such obligation, at least with the person threatened. Another asymmetry between promises and threats concerns the distinction between illocutionary and perlocutionary speech acts. Promises are assumed to be illocutionary since they deal with actions performed by a speaker. In the case of threats, however, the sense of perlocution is more apparent since threats involve the implication to the addressee.

Furthermore, Salguiro (2010: 216-219) distinguishes formal types of promises and threats.
Firstly, he distinguishes between elementary promise and threat and conditional promise and threat. Elementary promise is the one in which a promisor offers his/her promisee a reward for an action that he/she has performed to the benefit or satisfaction of the promisor. Utterance in (1) is one case in point.

(1) (I promise that) I will lend you my dictionary

In some cases, elementary promises can be an expression of generosity of a promisor to a loved-one. Elementary threats, on the other hand, are the ones in which a threatening party shows off or displays his/her power over the threatened party, despite the fact that the receiver does not do anything to warrant such a threat.

Turning to conditional promise and threat, Salguiro did not grant much attention. He merely said that both acts are conditional in nature. He gave more attention on commissive conditional promises $(C C P)$ or threats $(C C T)$ and directivecommissive conditional promises (DCCP) or threats (DCCT). The former promise or threat is the one in which a speaker's future action is conditional, but the objective of the promise or threat is not to get the addressee (the promisee or the threatened party) to bring about the satisfaction of the condition. Utterances (2) and (3) are respectively examples of CCP and CCT.

(2) If I pass Research Statistics course, I will give my dictionary to you.

(3) If I don't pass the exam, I will never treat you as a friend.

In utterance (2), the speaker does not get his/her addressee to realize the requirement of the satisfaction condition in the if clause. It is unlikely for the addressee to make the speaker pass Research Statistics course. Likewise, the threat in the main clause can be carried out without the involvement of the addressee. In other words, the addresser does not direct his/her addressee to fulfill the condition in the if clause. What happens in the if clause is not the addressee's responsibility, but the addresser's.

In a directive-commissive conditional promise (DCCP) or threat (DCCT), the main point is directive, and the future action is dependent on the satisfaction of the specified condition and the receiver's bringing about the fulfillment of the 
condition. See the examples in (4) and (5).

(4) If you send me to a book store, (I promise) I will buy you your favorite book.

(5) If you don't stop verbally bullying me, I will ......

In the utterances (4) and (5), the promise and the threat are dependent on the promisee and the threatened party, respectively. In case they can fulfill the requirement in the if clauses, the promise and the threat might happen.

\section{FINDINGS}

\section{Promise and Threat in Translated Verses of Law}

It is found that out of verses of law in marriage, inherritance, and trade, eight of them contain commissive acts, in particular the act of promise and threat. Acts of promise found in this study can be classified into three classifications: directive-commissive-conditional promise (DCCP), conditional-commissive promise (CCP), and neitherdirective-non-conditional promise (NDNCP). Dealing with the act of threat, it is found that directive-commissive-conditional threat (DCCT) is the only pattern of threat occuring in this study. Those commissive acts are syntactically realized in either conditional sentence or simple sentence. The classification of the commissive acts and their syntactical realization are presented in Table 1 .

Table 1

Commissive Acts in Translated Verses and their Syntactical Realizations

\begin{tabular}{l|l}
\hline \multicolumn{1}{c|}{ Commissive Acts } & Syntactical Realization \\
\hline \multirow{4}{*}{$\begin{array}{l}\text { Directive-Commissive- } \\
\text { ConditionalPromise } \\
\text { (DCCP) }\end{array}$} & $\begin{array}{l}\text { Simple Sentence } \\
\text { (declarative mood) }\end{array}$ \\
\cline { 2 - 2 } & $\begin{array}{l}\text { Simple Sentence } \\
\text { (negative declarative } \\
\text { mood) }\end{array}$ \\
\cline { 2 - 2 } $\begin{array}{l}\text { Commissive-Conditional } \\
\text { Promise (CCP) }\end{array}$ & Conditional Sentence \\
\hline $\begin{array}{l}\text { Neither-Directive-Nor- } \\
\text { Conditional Promise } \\
\text { (NDNCP) }\end{array}$ & $\begin{array}{l}\text { Simple sentence } \\
\text { (declarative mood) }\end{array}$ \\
\hline $\begin{array}{l}\text { Directive -Commissive- } \\
\text { Conditional Threat } \\
\text { (DCCT) }\end{array}$ & Conditional Sentence \\
\hline
\end{tabular}

\section{Directive-Commisive-Conditional Promises (DCCP) in Translated Verses of Law}

Data analysis suggests that there are four (4) promises in translated verses of law which can be categorized into directive-commissive-conditional promises. The verses are concerned with marriage, inherritance, and trade. All data are presented in Data (1), (2), (3), and (4).

Datum (1):

\section{The Translated Verse}

Wanita-wanita yang keji adalah untuk laki-lakiyang keji, dan laki-laki yang keji adalah buat wanita-wanita yang keji pula, dan wanita-wanita yang baik adalah untuk laki-laki yang baik dan laki-laki yang baik adalah untuk wanita-wanita yang baik pula. Mereka yang dituduh itu bersih dari apa yang dituduhkan oleh mereka yang menuduh itu. Bagi mereka ampunan dan rezeki yang mulia (surga) (QS: [24] Annur: 26)

The Original Verse

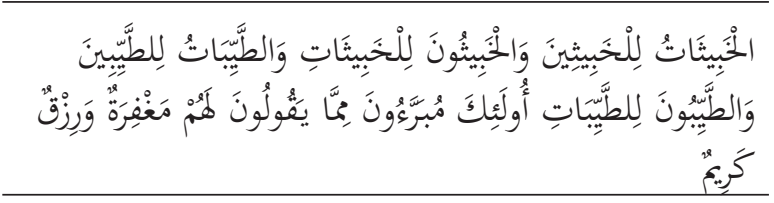

The verse is included into the verse of law in marriage since it deals with which person is appropriate for each. The first sentence says wanita-wanita yang keji adalah untuk laki-laki yang keji, dan laki-laki yang keji adalah untuk wanita yang keji pula, dan wanita-wanita yang baik adalah untuk laki-laki yang baik dan lakilaki yang baik adalah untuk wanita yang baik pula. The verse presents the appropriate spouse for each male and female person. The second sentence says mereka yang dituduh itu bersih dari apa yang dituduhkan oleh mereka yang menuduh $i t u$. It confirms that the third party is 'clean' or innocent. The last sentence saying bagi mereka ampunan dan rezeki yang mulia confirms that the speaker (Allah) promises to give a reward to the 'clean'-but-accused party: giving forgiveness and bountiful provision.

The promise, however, is not realized through a performative verb janji or 'promise'. Despite the absence of the performative verb janji, the promise is traceable from the use of the preposition bagi or for those at the beginning of the sentence. 
Indonesian grammar confirms that the preposition bagi functions to relate between two cases. In the context of the translated verse in Datum (1), the first case is the 'clean' or innocent party, and the second one is the forgiveness and bountiful provision. The logical relationship between being 'clean' or innocent and forgiveness are achievement and reward. Thus, the pseudo form is bagi mereka akan disediakan ampunan dan rezeki yang mulia (surga) or for those who are 'clean'-but-accused will be bestowed forgiveness and bounty provision.

Another indicator of the promise is that it fulfills the preparatory condition of a promise in a religious text: it is believed that doing the act is in the hearers' (man's) interest. In other words, it is believed that being forgiven and being given bountiful provision are the innocent-but-accused person's interest.

The promise in Datum (1) can be classified into directive-commissive-conditional promise (DCCP). The act of promise, which is stated in the last sentence, is initiated with a directive act: choosing an appropriate spouse. The realization of giving pardon and bounty provision is dependent on the receiver's bringing about the action. In case the receiver cannot fulfill the requirement, the promised condition would not be realized. By contrast, the action would not be realized if the required condition is fulfilled. As such, the main point of this promise is directing the receivers to do the required deeds.

Datum (2) that follows is quoted from the translated verses of QS An-Nisaa' [4]: 35. It deals with the rules of interaction between husband and wife.

Datum (2):

\section{The Translated Verse}

Dan jika kamu khawatirkan ada persengketaan antara keduanya, maka kirimlah seorang hakam dari keluarga laki-laki dan seorang hakam dari keluarga perempuan. Jika kedua hakam itu bermaksud mengadakan perbaikan, niscaya Allah memberi taufik kepada suami istri itu. Sesungguhnya Allah Maha Mengetahui lagi Maha Mengenal (QS AnNisaa' [4]: 35)
The Original Verse

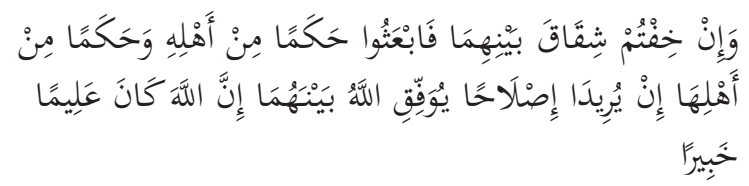

The act of promise lies in the sentence saying jika kedua hakam itu bermaksud mengadakan perbaikan, niscaya Allah memberi taufik kepada suami istri itu (lines 2-3) or if they both wish for peace, Allah will bestow help or aid. The linguistic indication of the promise is the use of conditional sentence indicated with the conjunction jika or 'if' in the clause saying jika kedua hakam itu bermaksud... or if they both wish for peace... and the use of the word niscaya or 'certainly' or 'surely' in the second clause: ...niscaya Allah memberi... or Allah will surely bestow .... The combination between them suggests that the fulfillment of the requirements (in the first clause) would bring about the realization of the act (in the second clause). The other indication of the act of promise is that the second clause contains the speaker's commitment to a future action: giving taufik or blessing to the husband and wife. The futureness is recognizable from the use of simple present tense which can be used for describing activities at present and in the future. The promised act, however, is not addressed to the receiver of the verse - the Prophet Muhammad - but it is for the third party, i.e. the breaching couple.

Viewed from the preparatory condition, the sentence fulfils the criteria of a promise since the act is necessarily in the receiver's interest. The receiver and the listeners of the verse are necessarily very happy if the breaching couple is blessed with taufik or blessing. The promise is included into directive-commissive-conditional promise (DCCP) since it is intended to motivate the arbiters to do their best in amending the dispute between the husband and wife.

Datum (3) that follows is a translated verse containing the law on inheritance; it is quoted from QS An-Nisaa' [4]: 13.

Datum (3): 


\section{The Translated Verse}

(Hukum-hukum tersebut) itu adalah ketentuanketentuan dari Allah. Barangsiapa taat kepada Allah dan Rasul-Nya, niscaya Allah memasukkanya ke dalam surga yang mengalir di dalamnya sungaisungai, sedang mereka kekal di dalamnya; dan itulah kemenangan yang besar (QS An-Nisaa' [4]: 13)

\section{The Original Verse}

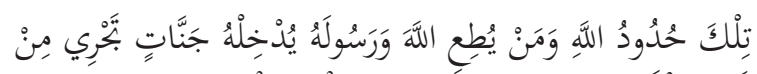

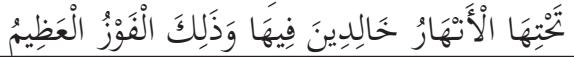

The verse is initiated with other five verses, all of which account for the rules of inheritance division. The act of promise lies in the second sentence of the verse saying barangsiapa taat kepada Allah dan Rasul-Nya niscaya Allah memasukkanya ke dalam surga yang mengalir di dalamnya sungai-sungai, sedang mereka kekal di dalamnya. The promise is recognizable from the linguistic representation and from the preparatory condition. Linguistically, the promise is traceable from the use of a conditional sentence composed of a condition clause: barangsiapa taat kepada Allah dan Rasul-Nya or ...whoever obeys Allah and His Messenger... and a result clause saying Allah akan memasukkannya ke dalam surga.... or ...He will make him enter Gardens underneath...., coordinated with a subordinating conjunction niscaya or surely. The existence of the subordinating conjunction niscaya confirms that the second clause is the subordinate of the first one. Or, in other words, the occurrence of the condition in the second clause is dependent on what happens in the first clause.

Referring to the Datum 3, the condition clause is the human's compliance to Allah and His messenger, while the result clause is the human's right to enter the Garden in which rivers flowing underneath. It suggests that entering the Garden is the result or the reward for obeying Allah and His Messenger. The speaker's commitment can be seen from the use of present tense indicating that the action can be done in the future. Viewed from the preparatory condition, the sentence suggests that the promised act in the second clause-He will make him enter Gardens underneath which rivers flow, where such will dwell forever-is the receiver's interest. Being entered into Gardens in which rivers flowing underneath is necessarily mankind's interest.

The promise is included into directivecommissive-conditional promise (DCCP).The use of a declarative sentence saying barangsiapa taat.... or whoever obeys Allah and His messenger .... is the marker of the directive act, and the use future tense is the marker of the commissive act. The uses of the conjunction niscaya or surely is the signal that the two clauses have term-and-condition relationship.

Datum (4) that follows is a verse of law on trade. It is quoted from QS Al-An'am [6]: 152. Datum (4)

\section{The Translated Verse}

Dan janganlah kamu dekati harta anak yatim, kecuali dengan cara yang lebih bermanfaat, hingga ia sampai dewasa. Dan sempurnakanlah takaran dan timbangan dengan adil. Kami tidak memikulkan beban kepada seseorang melainkan sekedar kesanggupannya. Dan apabila kamu berkata, maka hendaklah kamu berlaku adil kendatipun dia adalah kerabatmu dan penuhilah janji Allah. Yang sedemikian itu diperintahkan Allah kepadamu agar kamu ingat (QS: Al-An'am [6]: 152)

The Original Verse

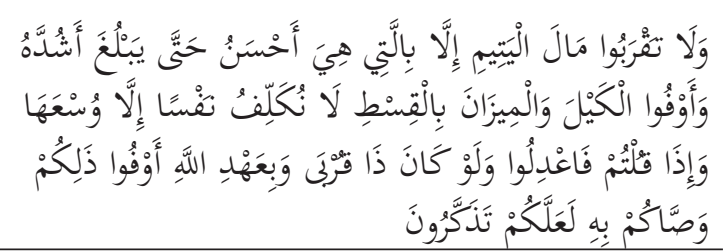

The promise lies in the second sentence saying Kami tidak memikulkan beban kepada seseorang melainkan sekedar kesanggupannya or We do no task any men beyond their capacity. The promise is initiated with two sentences having directive force. The first sentence says: Dan janganlah kamu dekati harta anak yatim, kecuali dengan cara yang lebih bermanfaat, hingga ia sampai dewasa (and come not near to the orphan's property, except to improve it, until he or she attains the age of full strength). In this sentence, the speaker (Allah) prohibits people from going near the wealth of orphans except with better ways until they attain their maturity. The second sentence says Dan sempurnakanlah takaran dan timbangan dengan 
adil(and give full measure and full weight of justice).The sentence suggests that Allah directs people to have full measure and weight in justice. Those sentences are followed by a promise saying Kami tidak memikulkan beban kepada seseorang melainkan sekedar kesanggupannya or We do not task any men beyond their scope.

The promise is realized in an indirect way, in the sense that the sentence can be interpreted in multiple interpretations. Firstly, it can be interpreted as the act of confirming. It confirms that Allah is the Beneficient and Merciful. He will never burden His creatures with problems which are beyond their scope. In addition, it can also be interpreted as a promise. The aspect of promise is recognizable from the use of simple present tense which can express both present and future actions. As such, kami tidak memikulkanor We do not task... can be elaborated into kami tidak akan memikulkan ... or We will not task... because of which it suggests the speaker's commitment to a future action. The use of the particle tidak inside the promise suggests that the Almighty Allah is committed not to do something in the future: tasking human beings beyond their capacity. The other indicator of a promise is the preparatory condition. Not being given task and burden beyond their scope is necessarily human being's interest. This condition confirms that the force behind the sentence is promise.

The promise in Datum (4) can be included into a directive-commissive-conditional promise (DCCP). The existence of two directive sentences preceding the promise imply that human beings are directed to do good deeds, i.e. approaching or managing the wealth of orphans proportionally, until they attain their mature ages, and giving full measure and weight in justice. The verse suggests that doing those good deeds are not hard since Allah has known the human's capacity.

\section{Commissive-Conditional Promises (CCP) in Translated Verses of Law}

It is found that one of the promises in the verses of law is included into commissive-conditional promise (CCP) as presented in Datum (5).
Datum (5)

\section{The Translated Verse}

Dan kawinkanlah orang-orang yang sendirian diantara kamu, dan orang-orang yang layak (berkawin) dari hamba-hamba sahayamu yang lelaki dan hambahamba sahayamu yang perempuan. Jika mereka miskin Allah akan memampukan mereka dengan kurnia-Nya. Dan Allah Maha Luas (Pemberian-Nya) lagi Maha Mengetahui (QS: Annur [24]: 32)

The Original Verse

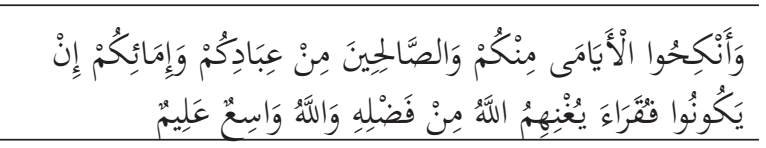

The verse is concerned with the law of marriage. The verse consists of two sentences, each of which has a different act. The illocutionary force of the first sentence saying Dan kawinlah orangorang yang sendirian diantara kamu dan orangorang yang layak (berkawin) dari hamba-hamba sahayamu yang lelaki dan hamba-hama sahayamu yang perempuan is directive since it instructs to marry appropriate persons. The second sentenceJika mereka miskin Allah akan memampukan mereka dengan kurnia-Nya-is a conditional sentence which is composed of two clauses: a condition and a result clause. The condition clause says jika mereka miskin or if they are poor, and the result clause says Allah akan memampukan mereka dengan kurnia-Nya or Allah will enrich them out of His Bounty. The act of promise lies in the result clause. The sense of promise is recognizable from the commitment of the speaker (Allah) to future actions: enriching and empowering those who are poor with His bounty. Another indicator of a promise is that the promised actions-enriching and empowering - are in the receivers' interest. Being enriched and empowered are necessarily of man's interest.

The promise is categorized into commissive conditional promises (CCP). In the context of this verse, the realization of the enrichment and empowerment is dependent on the condition of the persons to whom the promisee will marry with. If they are poor, Allah promises that they will 
be enriched and empowered. Thus, the promise is made not because to direct the promisee to do something, but it is for eliminating the bad condition described in the conditional clause.

\section{Neither-Directive-Nor-Conditional Promise (NDNCP) in Translated Verses of Law}

Data analysis suggests that three (3) promises are neither DCCP nor CCP, instead they are made merely as the expression of generosity of the Almighty Allah. The verses are QS An-Nisaa' [4]: 26, 27, 28, respectively presented in Data(6), (7), and (8). Those verses are initiated with four other long verses specifying the forbidden and the allowed women to marry (QS: An-Nisaa' [4]: 22$25)$. As such, the ones containing the act of promise in Data (6), (7), and (8) are part of those previous verses.

Datum (6)

\section{The Translated Verse}

Allah hendak menerangkan (hukum syariat-Nya) kepadamu, dan menunjukimu kepada jalan-jalan orang yang sebelum kamu (para nabi dan shalihin) dan (hendak) menerima taubatmu. Dan Allah Maha Mengetahui lagi Maha Bijaksana (QS An-Nisaa' [4]: 26)

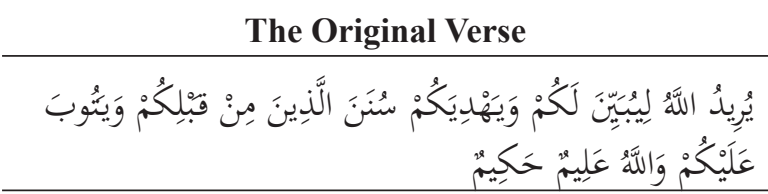

Specifying the forbidden and allowed women to marry, the Almighty Allah provides with a promise in verse 26 as quoted in Datum (6). The act of promise in Datum (6) lies in the sentence saying Allah hendak menerangkan (hukum syariat-nya) kepadamu, dan menunjukimu jalan-jalan orang yang sebelum kamu (para nabi dan shalihin) dan (hendak) menerima taubatmuor Allah wishes to make clear (what is lawful and what is unlawful) to you, and to show you the ways of those before you and accept your repentance. The lexical choice indicating the act of promise is the use of the word hendak which means akan or would or be going to. The use of the time signal hendak suggests that the speaker intends to do something, i.e., explaining the syariat or guidance guiding the receiver (the Prophet Muhammad) through the examples of those before him, and turning the receiver in mercy. Besides, it can be considered to be a promise because it can be believed that the promised future actions are in the receiver's interest. Being given explanation and guided through the examples of people before the receiver, and being turned into mercy are necessarily valuable for him.

The promise in Datum (6), however, cannot be included into commissive conditional promise (CCP) nor directive-commissive-conditional promise (DCCP). The promise in Datum (6) does not specify what condition should be fulfilled in order that the act of explaining the syari'at or guidance, guiding the receiver through the examples of people in the past, and turning the receiver in mercy can be realized.

Datum (7) that follows presents the act of promise. It is quoted from QS An-Nisaa [4]: 27. Datum (7)

\section{The Translated Verse}

Dan Allah hendak menerima taubatmu, sedang orang-orang yang mengikuti hawa nafsunya bermaksud supaya kamu berpaling sejauh-jauhnya dari kebenaran (QS An-Nisaa' [4]: 27)

The Original Verse

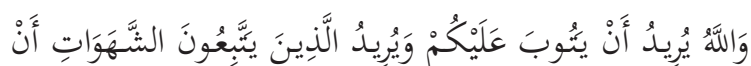

$$
\begin{aligned}
& \text { تَمَيُوا مَيْلَاً عَظِيمًا }
\end{aligned}
$$

The act of promise lies in the independent clause; it says dan Allah hendak menerima taubatmuor And Allah wishes to accept your repentance... The diction indicating the commitment to the future action is the use of the word hendak or akan or wishes, which means that the action is going to be undertaken in the future. The use of the word hendak suggests that it is in future tense. The future action in the verse is accepting the receiver's (the Prophet Muhammad) repentance. The promised future action is necessarily in the receiver's interest. It can be guaranteed that being accepted the repentance is in human's interest, including the receiver.

The promise in Datum (7) cannot be included into commissive conditional promise (CCP) nor directive-commissive-conditional promise (DCCP). It does not account for the conditions 
that must be fulfilled for the promise, and it is not intended to direct the receiver to do something as the requirements for the promise, either. The promise is neither initiated with any directive act requiring the receiver to do something nor provided with any conditions. As such, the promise in Datum (7) is the expression of the generosity of Allah to His creatures.

The other act of promise can be seen in Datum (8).

Datum(8)

\begin{tabular}{|c|}
\hline The Translated Verse \\
\hline $\begin{array}{l}\text { Allah hendak memberikan keringanan kepadamu, } \\
\text { dan manusia dijadikan bersifat lemah (QS An-Nisaa' } \\
\text { [4]: 28) }\end{array}$ \\
\hline The Original Verse \\
\hline 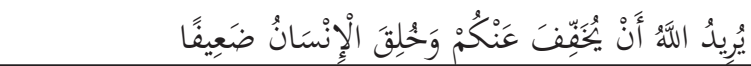 \\
\hline
\end{tabular}

It consists of a single sentence, and the promise is traceable from the use of future tense indicated with the word hendak or akan, which means would or be going to. The verse suggests the commitment of Allah to a future action: making the burden of the receiver (the Prophet Muhammad) light. The act is believed to be in the promise's interest. All humans, including the receiver of the verse or the promise (the Prophet Muhammad) would be very happy if the burden is made light.

The promise in Datum (8) cannot be included into commissive-conditional promises (CCP) nor directive-commissive-conditional promise (DCCP). The promise is not initiated with any directive act directing the receiver to do something, nor is provided with the condition or the requirement that must be fulfilled. Like the previous promise in Datum (7), the promise is the expression of the generosity of Allah.

\section{THREAT IN TRANSLATED VERSES OF LAW}

This study reveals that the act of threat occurs only once.

\section{Directive-Commissive-Conditional Threat (DCCT)}

It was found that the act of threatening does not frequently appear in the translated verses of law in the Qur'an; this study reveals that there is one translated verse containing the act of threat, as displayed in Datum (9).

Datum (9)

The Translated Verse

Dan barangsiapa mendurhakai Allah dan RasulNya dan melanggar ketentuan-ketentuan-Nya, Niscaya Allah memasukkannya ke dalam api neraka sedang ia kekal di dalamnya; dan baginya siksa yang menghinakan (QS An-Nisaa' [4]: 14)

The Original Verse

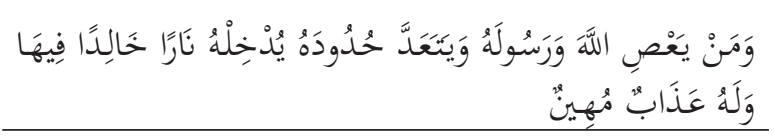

The verse is initiated with six other verses; the first five verses account for the rules of inheritance division, while the other one contains the promise for those obeying Allah and His Messenger as presented in Datum (7). Datum (9) presents the speaker's commitment to a future action: making human beings enter Fire and making them dwell in it forever. The force behind the sentence is threatening. The act of threat in Datum (9) lies in the second clause of the first sentence saying niscaya Allah memasukkannya ke dalam api neraka sedang ia kekal di dalamnya; dan baginya siksa yang menghinakan or ...He will make them enter Fire in which they will dwell in forever. The clause is initiated with another one containing the condition triggering the occurrence of the threat; it says dan barangsiapa melanggar ketentuanketentuan Allah dan Rasulnya... or and those disobey Allah and His Messenger and transgress His limits....

The threat is recognizable from the linguistic representation and preparatory condition. Linguistically, the use of a conditional sentence containing two clauses is the evidence of the threat. The first clause contains the reason of the occurrence of the threat in the second one. As such, the threat will never occur if the bad condition in the second clause does not appear. In other words, Allah will not make humans enter Fire if they do not disobey Him and His Messenger and if they do not transgress His limits.

In addition, viewed from the preparatory condition, the force behind the sentence is threat since the future act is not in the receiver's interest. 
Being put or entered into Fire is necessarily not in human's interest. The threat is included into directive-commissive-conditional threat (DCCT) since it is intended to direct human beings not to disobey Allah and His messenger and not to transgress His limits.

\section{DISCUSSION}

What can be learnt from these findings? To my view, there are, at least, three points worth learning: the occurence of directive-commissiveconditional promise (DCCP) and directivecommissive-conditional threat (DCCT), the existence of commissive-conditioanl promise (CCP) and neither-directive-nor-commissive promise (NDNCP), and the dominance of promise over threat.

As touched on earlier, DCCP is the most frequently-occurring pattern of promise, while DCCT is the only pattern of threat appearing in this study. These findings confirm the Shihab's statement saying that making promises and ordering threats is one of the strategies used to convey the messages in the Qur'an (2013: 91).

The question is: why are the verses of law realized through DCCP and DCCT? The nature of law and the nature of humans might answer the question. Law is rules of life. It is the rules made by a government stating what people may or may not do in society. In other words, law is the border that people should not cross. It suggests that law directs people to behave properly and prevent them from the wrongdoing. Law is commonly provided with sanctions for those disobeying it. Law in the holy Qur'an is substantially not different from the one made by humans. Law in the Qur'an is designed to regulate and alter human's behavior. It directs people how to behave properly in all aspects of life.

Relying on the nature of law, it can be deduced that promise of reward in the verses of law containing DCCP is an instrument to stimulate humans to perform good deeds, while threat of punishment in DCCT is the one functioning to prevent humans from wrongdoing. It is believed that humans, by nature, are reward-and-punishment sensitive. Humans will be easily driven to perform good deeds as suggested in the verses of law if they are beneficial for them. Forgiveness and bountiful provision (datum 1), taufik or blessing(datum 2),
Garden with rivers flowing underneath (datum 3), and not tasking them beyond their capacity (datum 4) are examples of rewards which might drive humans to perform good deeds. On the other hand, humans are punishment-sensitive as well. Humans will be easily driven to avoid inconvenience and misery. In consequence, any deeds that might result in inconvenience and misery are necessarily avoided. Relying on humans' sensitivity to reward and punishment, it is plausible that the verses of law are realized through DCCP and DCCT. Through those patterns, humans can easily be directed to race in the right tract and not cross the border.

The other findings worth discussing are the existence of commissive-conditional promise (CCP) and neither directive-nor-commissive promise (NDNCP). Linguistically, CCP and NDNCP are different from DCCP since DCCP explicitly denotes the act of direction, but $\mathrm{CCP}$ and NDNCP do not. Despite the absence of the direct direction, it can be believed that the force behind those verses is directing. This belief is based on the fact that law, including the one in the Qur'an, is intended to direct people to live life in proper and orderly ways. As such, promises in DCCP, CCP, and NDNCP have the same function: as the instrument to stimulate human to perform good deeds.

The verses containing CCP and NDNCP, however, do not mention that human will be rewarded on condition that they have done certain good deeds. The promises in data 5, 6, 7, and 8 , on the surface, do not stimulate humans to perform good deeds. They do not provide with the requirements requiring humans to perform good deeds in return for the promise of rewards. Those verses, however, are initiated with other verses directing and instructing marrying appropriate persons (Datum 5), and specifying the forbidden and allowed women to marry (Data 6, 7, and 8). It suggests that the promises in CCP and NDNCP are the reward for those obeying the law presented in the previous verses: marrying appropriate persons. This tenet is based on the fact that verses in the Qur'an are related to each other. The arrangement of verses in the Qur'an is not based on the chronological order of time, but it is based on the interconnectedness among them (Shihab, 2013: 
209). From this, it can be underlined that the verses of law containing either CCP or NDNCP function to direct people to perform good deeds, albeit without explicit direction.

The next point worth discussing is the existence of the acts of promise and threat. The existence of both promise of rewards and threat of punishments confirms that the Qur'an is arranged in balance, particularly at the speech act level. Naufal explained that the balance in the Qur'an can be seen from the number of words and their antonyms and synonyms, the number of words and their references referring to their impacts, and the number of words and the cause of it (cited in Shihab, 2014: 147). In the context of this research, the balance can be seen from the existence of promises and threats. Those acts suggest two contradictory effects: rewards and punishments. The juxtaposition between promise and threat is the representation of the balance since rewards and punishments are identical with two sides of a single coin. This is because each person has his own way in viewing the law. Some of them consider that obeying the law in the Qur'an is compulsory, but some of them do not. Due to the heterogeneity, making the balance between rewards and punishments is a good strategy to drive people to obey the law. The existence of promise and threat found in this study confirms the statement in the Qur'an saying: It is Allah who has sent down the Book in truth and (also) the balance. And what will make you perceive? Perhaps the Hour is near (Surah Asy-Syura [42]: 17).

Dealing with the number of promises and threats found in this study, it can be reiterated that the act of promise appears eight times presented in Data 1-8, and the act of threat occurs one time, stated in Datum 9. The imbalanced number of occurrences of those acts is by no means that it contradicts or rejects the truth of the Surah AySyura [42]: 17 cited earlier. The present study studies very limited number of the verses of law; it studies the law in three domains: marriage, inheritance, and trade. As a matter of fact, the laws in the Qur'an are not concerned with only those domains. Many other laws are massively discussed in the Holy Book. Relying on this, the findings of this study cannot be made as a generalization. It needs some other studies through which a generalization on the verses of law in the Qur'an can be made.

\section{CONCLUSION}

To recapitulate, this study reveals that the acts of promise and threat are present in the translated verses of law in the Qur'an, in particular in the verses concerning marriage, inheritance, and trade. The promise occurring in those verses can be classified into DCCP, CCP, and NDNCP, and DCCT is the only pattern of threat found in this study. Those patterns are syntactically realized through conditional sentences and simple sentences.

The conclusion that can be drawn from those finding is that at speech act level, the translated verses of law in the Qur'an are balanced. The presence of promise and threat within the verses of law is the evidence. As such, the findings of this research reinforces the Naufal's study revealing that the Qur'an is linguistically balanced at the level of word and phrase.

\section{ACKNOWLEDGEMENT}

This research was funded by the General Directorate of Islamic Higher Education of the Ministry of Religious Affairs of the Republic of Indonesia under the Collective Competitive Grant 2014.

\section{REFERENCES}

Al-Jawadi, K.H. \& Abdul-Majeed, R.K. (2007). Modification of Searle's speech act of promising in its application to selected religious and political texts. Journal of College of Education for Women, 18(1), 287300. Retrieved from http://www.iasj.net/ iasj?func $=$ fulltext\&aId $=2033$, on November $11,2014$.

Austin, J.L. (1975). How to do things with words (2nd ed.). Oxford: Oxford University Press.

Blum-Kulka, S., House, J., \& Kasper, K. (1989). Investigating cross-cultural pragmatics: An introductory overview. In S. Blum-Kulka, J. House, \& K. Kasper, (Eds.), Cross-cultural pragmatics: Requests and apologies (pp. 1-34). Norwood, NJ: Ablex Publishing.

Departemen Agama Republik Indonesia. (1990). AlQur'an dan terjemahnya. Jakarta.

Khallaf, S.A.W. (1947). Kitab ushul fiqih. Kairo: Maktabah Ad-Dakawah Al-Islamiyah. 
Salguiro, A.B. (2010). Promises, threats, and the foundations of speech act theory. Pragmatics 20(2), 213-228. Retrieved from http:// elanguage.net/journals/pragmatics/article/ download/2569/2530, on November 11, 2014.

Searle, J. (1976). A classification of illocutionary acts. Language in Society, 5(1), 1-23. Retrieved from http://www.jstor.org/stable/4166848, on April 9, 2009.
Shihab, M.Q. (1996). Wawasan Alqur'an tafsir maudhui atas pelbagai persoalan umat. Jakarta: Mizan. . (2013). Membumikan Al-Qur'an (2 ${ }^{\text {nd }}$ ed.). Bandung: Mizan.

(2014). Mukjizat Al-Qur'an ditinjau dari aspek kebahasaan, isyarat ilmiah, dan pemberitaan gaib (New ed.). Bandung: Mizan. 